\title{
Direction of Regulating Catcall Actions in Law: Comparison of Indonesia and France Law
}

\author{
Evelyne Julian Halim \\ Faculty of Law, Universitas Tarumanagara, Jakarta, Indonesia \\ Email: evelynejh@gmail.com \\ ORCID Link: https://orcid.org/0000-0002-3852-2627
}

\section{Citation:}

Halim, E. J. (2021). Direction of Regulating Catcall Actions in Law: Comparison of Indonesia and France Law, Lex Scientia Law Review, 5(1), 63-82, doi: https://doi.org/10. 15294/lesrev.v5i1.46376

\section{History of Article}

Received: April 15, 2021

Revised: May 17, 2021

Accepted: May 27, 2021

(C) The Author(s)

\section{(c) (i) 8 (2)}

This work is licensed under a Creative Commons Attribution-NonCommercialShareAlike 4.0 International License. All writings published in this journal are personal views of the authors and do not represent the views of this journal and the author's affiliated institutions.

Lex Scientia Law Review published by Faculty of Law, Universitas Negeri Semarang, Indonesia in collaboration of UKM Lex Scientia. Published biannually every May and November.

\begin{abstract}
Various forms of harassment in the world are increasing, including in Indonesia. Women and children are the most frequent victims of sexual harassment, but it does not rule out that men can become victims. Catcalling is an act that has sexual implications for the victim with teasing, whistling, screaming, comments, and eye contact on the street or in public places. Sexual harassment negatively impacts victims such as shame, offense, humiliation, anger, loss of self-esteem, loss of chastity, depression, etc. Writing this scientific article aims to provide reference material for lawmakers regarding the ideal regulation of street harassment, especially catcalling. Then, give the readers an understanding of catcalling and the urgency of its rule in Indonesian legislation. The method used in this scientific article is a normative juridical method with data collection techniques using literature study by examining secondary data, namely statutory regulations, other legal documents, research results, assessment results, and other references. This study uses a statute approach, conceptual approach, and comparative approach. This verbal sexual harassment has been taken seriously in several countries, such as France. In France, this anti-catcalling Law is known as Loi Schiappa. Loi Schiappa gave direct fines to the perpetrators of catcalling. In Indonesia, there is no regulation regarding catcalling, resulting in a legal vacuum. Indonesia can follow the model of the French Catcalling arrangement, which uses direct fines on the spot. So that provides legal
\end{abstract}


certainty as well as protects the human rights of victims of catcalling.

\section{KEYWORDS}

Catcalling; Loi Schiappa; Sexual Harassment

\section{INTRODUCTION}

Various forms of harassment in the world are increasing, including in Indonesia. Women and children are the most frequent victims of sexual harassment, but it is possible that even men can become victims. Sexual harassment is any form of sexual behavior committed by a person or several people that the victim does not like or expect. It harms the victim, such as shame, offense, humiliation, anger, loss of self-esteem, loss of sanctity, and so on. Sexual harassment includes flirting, naughty whistling, comments with sexual connotations, pornographic humor, pinching, poking, clapping, or touching certain parts of the body, gestures of a sexual nature, asking for dates with the lure of threats, asking for sex, to rape. In other words, sexual harassment is 1) Abuse of sexual behavior; 2) Requests to commit sexual acts (invitation to commit sexual acts, date requests); 3) Verbal or physical statements of doing or gestures depicting sexual acts (messages that display sexually explicit content in printed or electronic form (SMS, Email, Screens, Posters, Compact Disks, etc.); 4) Unwanted acts of sexual orientation. Sexual harassment can occur anywhere and anytime, such as on buses, factories, supermarkets, cinemas, offices, hotels, sidewalks, both day and night. ${ }^{1}$

This certainly makes victims of sexual harassment feel insecure, even though Article 30 of Law Number 39 of 1999 concerning Human Rights (Human Rights Law) states that everyone has the right to a sense of security and peace and protection against the threat of fear. Moreover, this sense of security is guaranteed in the constitution of the Republic of Indonesia as stated in Article 28G paragraph (1) of the 1945 Constitution of the Republic of Indonesia (hereinafter as UUD NRI 1945), which says that everyone has the right to protection of personal, family, honor, dignity, and property under its control, and are entitled to a sense of security and safety from the threat of fear to do or not do something which is a human right. However, research consistently shows that these seemingly "minor" and "every day" distractions are a routine part of negotiating public and semi-public spaces. Statistics

\footnotetext{
${ }^{1}$ Dewi Fiska Simbolon, “Minimnya Pendidikan Reproduksi Dini Menjadi Faktor Penyebab Terjadinya Pelecehan Seksual Antar Anak", Soumatera Law Review, Volume 1 Number 1, 2018, p. 56-57. 
suggest that as many as 90 percent of women experience street harassment at least once in their lives. ${ }^{2}$

The National Commission on Violence Against Women (hereinafter as Komnas Perempuan) notes that the number of women who become victims of violence increases every year. The violence that occurs includes physical, psychological, and sexual violence. ${ }^{3}$ Komnas Perempuan notes that sexual violence is one of the most common forms of violence. Between 2001 and 2011, cases of sexual violence account for an average of one-quarter of reported cases of violence against women. ${ }^{4}$ Komnas Perempuan identified 15 (fifteen) forms of sexual violence, one of which was sexual harassment. The definition of street harassment or in English, called street harassment, is a series of spread actions, such as catcalling, wolf-whistling, prolonged staring or glancing, groping, following someone and intuitive verbal comments. Catcalling occurs mainly in public places and is carried out by strangers who do not know each other. Examples of catcalling are often found such as "ssuit ... ssuit ...", "Hi, beautiful", "Darling", "Where are you going, miss? Let's stay with you, "How come you're alone? "," Hi, girl! Arrogant doesn't want to answer?", and so on.

Many countries have taken sexual harassment seriously at this time, one of which is France. In France, Loi Schiappa regulates verbal sexual harassment ${ }^{5}$, which took effect in August 2018. One year after the Law was enacted, more than 700 men have been fined for harassing women in public. Men who break the law face potential on-site fines of up to 750 euros or 1,500

\footnotetext{
2 Bianca Fileborn, “Justice 2.0: Street Harassment Victims' Use Of Social Media And Online Activism As Sites Of Informal Justice", British Journal Of Criminology, Volume 57 Number 6, 2016, p. 14821501.

3 Dewan Perwakilan Rakyat, Naskah Akademik Rancangan Undang-Undang tentang Penghapusan Kekerasan Seksual, 2017, p. 2.

${ }^{4}$ Komnas Perempuan's 10-year study of Komnas Perempuan's Annual Notes (Catahu) on Violence against Women in Indonesia shows that cases of sexual violence always occur, so that in 2012 Komnas Perempuan concluded that at least 2 women were victims of sexual violence every 3 hours. See Komnas Perempuan, "Siaran Pers Peluncuran Laman Kekerasan Seksual," accessed from http://www.komnasperempuan.go.id/siaran-pers-peluncuran-laman-pengaduan-kekerasanseksual/, also on Naskah Akademik Rancangan Undang-Undang tentang Penghapusan Kekerasan Seksual, 2017, p. 2.

${ }^{5}$ Stéphanie Fillion, "2 Years Later, What We Can Learn From France's Anti-Catcalling Law", Forbes, January 26 2021, accessed from https://www.forbes.com/sites/stephaniefillion/2021/01/26/2-yearslater-what-we-can-learn-from-frances-anti-catcalling-law/?sh=208cdae375dc.
} 
euros if aggravating circumstances such as victims under 15 years of age. ${ }^{6}$ In Indonesia itself, there are no clear rules regarding this catcalling. So far, it has only used a mixture of articles in the Criminal Code (KUHP) and Law Number 44 of 2008 concerning Pornography to ensnare catcallers. Referring to this problem, it is necessary to study the catcalling arrangement in France, which has already made a legal rule known as Loi Schiappa? and what is the direction of catcalling regulation in Indonesian positive Law?

The purpose of writing this scientific article is to provide reference material for lawmakers regarding the regulation of street harassment, especially ideal catcalling, and give the readers an understanding of catcalling and the urgency of its rule in Indonesian legislation. The act of catcalling has made the victim feel insecure and violates the human rights of the victim. The author will use the theory of human rights which refers to Law Number 39 of 1999 concerning Human Rights. Talking about the human rights of victims, it is inseparable from legal protection for victims. In addition, the author will examine the direction of catcalling arrangements for punishment.

\section{METHOD}

The simple definition of a research method is the procedure for conducting research. The research method talks about the procedures for conducting research. ${ }^{7}$ The research method used is the normative juridical method with data collection techniques using literature study by examining secondary data, namely statutory regulations, other legal documents, research results, assessment results and other references. This study uses a statutory approach (statute approach), a conceptual approach (conceptual approach) and a comparative approach (comparative approach).

\section{RESULT AND DISCUSSION}

\section{A. Catcalling Arrangement in French}

Sexual harassment has been a longstanding issue in the world. Although there has been researched on sexual harassment and its effects, sexual harassment still cannot be appropriately handled by the justice system. This is due to many cases of sexual harassment where victims do not report it

\footnotetext{
${ }^{6}$ Emma Batha, "France Fines More Than 700 in First Year of 'Cat-call' law", Reuters, August 6, 2019, accessed from https://www.google.com/amp/s/mobile.reuters.com/article/amp/idUSKCN1UW1NY.

7 Jonaedi Efendi, Johnny Ibrahim, Metode Penelitian Hukum: Normatif dan Empiris, Prenadamedia Group, Depok, 2018, p. 2. 
to law enforcement officials and victims are often complicated in reporting due to a lack of evidence. Catcalling is also included in it. As we know, catcalling is an act that has sexual implications for the victim with teasing, whistling, screaming, comments and even eye contact on the street or in public places. Some definitions also include acts that fall within the legal definition of rape and sexual violence. ${ }^{8}$ In the oxford dictionary, catcalling is translated as whistles, calls and comments of a sexual nature. Sometimes this is accompanied by a look that is harassing that makes women uncomfortable. ${ }^{9}$ This definition is also in line with that expressed by Chun that: "catcalling as the" use of wild places in public areas such as streets, sidewalks, or bus stops. Verbal expressions of catcalling tend to involve wolf-whistles or comments that evaluate a woman's appearance. Nonverbal expressions often include leers and physical gestures that act as a means to rate a woman's physical appearance. ${ }^{10}$ The phenomenon of catcalling has been used as the object of research conducted by Benard and Schlaffer which revealed that when women are on the street they often face harassment regardless of age, dress, race or even socio-economic level.

In recent years street harassment has become a concern, especially in cyberspace, because victims who experienced sexual harassment recorded their experiences when they were harassed. Websites such as Holla, Back !, Stop Street Harassment, Never Okay Project and Instagram @dearcatcallers.id are some of the many platforms that bridge abuse victims to discuss their experiences and inform the public about instances of calls and harassment they have experienced. Movements that reject street harassment and increase the trust of victims to service provider institutions are not accompanied by the availability of legal remedies for individuals who are perpetrators of this harassment. ${ }^{11}$ Sexual offenses (moral offenses) and sexual harassment (sexual

\footnotetext{
${ }^{8}$ Bianca Fileborn \& F. Vera Gray, "I Want to be Able to Walk the Street Without Fear: Transforming Justice for Street Harassment", Feminist Legal Studies, Volume 25 Number 2, 2017, p. 205.

9 Purnama Ayu Rizky, "Catcalling dan Mimpi Buruk Perempuan di Jalan”, alinea.id, March 18, 2018, accessed from https://www.alinea.id/gaya-hidup/catcalling-dan-mimpi-buruk-perempuan-di-jalanb1UvT9I8.

${ }^{10}$ Collen O' Leary, "Catcalling As a "Double Edged Sword": Midwestern Women, Their Experiences, and The Implications of Men's Catcalling Behaviors", Theses and Dissertation, Illinois State University, 2016, p. 32.

${ }^{11}$ Ida Ayu Adnyaswari Dewi, "Catcalling: Candaan, Pujian atau Pelecehan Seksual", Acta Comitas Jurnal Hukum Kenotariatan, Volume 4 Number 2, 2019, p. 200.
} 
harassment) are two forms of violation of decency: a global legal problem. Perpetrators of decency crimes and sexual harassment are not dominated by those who come from middle or low economic groups, let alone less or have no education at all. Still, the perpetrators have gone through all social strata from the lowest to the highest strata. ${ }^{12}$

Launching The boar.org, 450,000 women experience sexual harassment each year. 85 percent of 18-24 year olds have been sexually harassed in public with 90 percent of them experienced before 17.13 Likewise, in 2016, a survey conducted by the international non-governmental organization, ActionAid, revealed that 75 percent of women in London, 79 percent of women living in cities in India, 86 percent of women in Thailand, and 89 percent women in Brazil have experienced harassment or violence in public. The research results conducted by Coleen O'Leary show that there are still many men who consider their greetings and compliments to be a form of praise even though women don't see it that way. This proves that the gender gap in society in the world is still inherent.

The prevalence of sexual harassment against women indicates a social construction that still places women as weak and second-class creatures. Women often experience discrimination and are targets of hatred. Verbal sexual harassment has been taken seriously in many countries, such as the United States, Philippines, France, Argentina, Belgium, Portugal and Peru. In France this anti-catcalling Law is known as Loi Schiappa. The name Schiappa is taken from the name of the former French gender equality minister, Marlene Schiappa. The formation of this anti-catcalling Law was set in the background of July 22, 2018, when architecture student Marie Laguerre was walking past a cafe when a man greeted her and then made "dirty noises and comments." Laguerre told her to shut up and the man slapped her after she finally closed his mouth. This incident was witnessed by many people and even recorded on CCTV. Laguerre then uploaded the CCTV footage of the incident and uploaded it to YouTube. The video was viewed over a million times in 48 hours, making many people angry. This incident became a hot topic of a national discussion about sexual harassment experienced by women. The issue of sexual harassment against women in France has started

\footnotetext{
${ }^{12}$ Adami Chazawi, Tindak Pidana Mengenai Kesopanan, Raja Grafindo Persada, Jakarta, 2005, p. 2.

${ }^{13}$ Emma Wilkes, "The Dangerous Impact of Catcalling on Women", The Boar, February 11, 2021, accessed from https://theboar.org/2021/02/catcalling-experiences/.
} 
with the appointment of Schiappa as minister of gender equality by President Emmanuel Macron.

According to a 2018 French national poll, eight out of 10 women in France have experienced street harassment compared with 65 percent in the United States and 64 percent in the UK. Since the movement \#Metoo ${ }^{14}$ globalizing, women in France refuse to accept harassment as a part of their lives. On August 5, Loi Schiappa, the Law on verbal sexual harassment, was born that same year. This Law was a revolution in introducing sexism into French Law. Because in French civil and criminal Law there is no definition of sexism ${ }^{15}$. The legal aspect of incorporating catcalling sexual harassment into the Law is to sanction perpetrators of sexual harassment, including catcalling and raise their awareness of catcalling.

Catcalling law enforcement fills the legal vacuum in France because catcalling has been around for a long time and no law can ensnare the perpetrators. Under this Law, offenders of street sexual harassment can be fined on the spot, eliminating the need to carry out an investigation or go to a police station. The model of direct fines to the perpetrators of catcalling was chosen because it took into account that most victims tended not to report it to the police. Apart from that, the formation of this anti-catcalling Law also took an example in Belgium, which made catcalling a crime. It turned out to be this Belgian mode ${ }^{16}$ does not work well because the victim has to file a complaint, then there will be an investigation and then going to the prosecution. The prosecution will check the investigation documents. The court will then

\footnotetext{
${ }^{14}$ The \#MeToo movement in France is known as \#BalanceTonPorc. This wave of feminism is a modern view that has evolved digitally from the traditional pillars of the women's movement which raises women's awareness to share stories about gender-based violence from their experiences. The \#MeToo wave has created a more open social climate for discussing gender-based violence, including sexual harassment on the street. See Denise Brunsdon, Legal Solutions to Street Sexual Harassment in the \#MeToo Era, Atlantis, Volume 39 Number 2.

${ }^{15}$ In Merriam Webter's Dictionary defines sexism as prejudice or discrimination based on sex, which is present in the form of violence and sexual crimes. Sexism can occur in both men and women, but it is often women who are victims of sexism in society. See Helenerius Ajo Leda, "Seksisme dan Kekerasan Seksual Di Flores" accessed from https://osf.io/r7zsg/.

${ }^{16}$ Hukum anti-catcalling Belgia disebut Loi Sexisme yang mulai diberlakukan pemerintah Belgia pada tahun 2014. See The IWI: International Women's Initiative, "Street Harassment: The Inadequacy of European Laws", accessed from https:/www.theiwi.org/gpr-reports/belgium-france-portugalcatcalling-law. Also on Stéphanie Fillion, "2 Years Later, What We Can Learn From France's AntiCatcalling Law", accessed from https://www.forbes.com/sites/stephaniefillion/2021/01/26/2-yearslater-what-we-can-learn-from-frances-anti-catcalling-law/?sh=208cdae375dc.
} 
impose a 1000 euro fine and a prison sentence of up to one year. This French model is more efficient and time-saving because the victim only needs to go to a police officer on the street and the police will immediately fine-tune the perpetrator. However, a legal concept like this would reduce the idea of street sexual harassment to a simple offense punishable by a fine. This would undermine the clear message to society that harassing someone is equivalent to jumping a red light without fully recognizing its underlying intent and implications for the Law. As long as the perpetrators feel unpunished, they will continue to claim that the city, its streets, and its inhabitants are theirs. ${ }^{17}$

Apart from the positive development of catcalling Law, there are still some challenges in enforcing this catcalling Law. Because the general public still considers catcalling as a regular act and law enforcement officials such as the police do not understand well what catcalling is. Apart from that, there is also a culture of blaming the victim, so that in the end it gives a burden to the victim and in the end the victim does not report the law enforcement apparatus. The average catcalling victim will feel uncomfortable, annoyed, embarrassed, and even afraid. According to a psychological survey based in New Jersey, catcalling can cause victims to make self-judgments like selfobjectification unconsciously. ${ }^{18}$

\section{B. Catcalling Arrangement in Indonesia}

Street sexual harassment is still considered commonplace and even seems to be tolerated in Indonesia. Even though this catcalling act has a bad impact on the victim. Women are often victims of this catcalling, although there are also men who are victims of catcalling. Catcalling experienced by women occurs because of the sociocultural construction of a patriarchal society, which places women as weak and inferior creatures compared to men. The difference in gender roles between men and women has created various injustices, both for men, especially for women. According to Mansour Fakih, gender injustice is manifested in multiple forms of injustice, namely:19 (1) Marginalization or the process of impoverishing women; (2) Subordination

17 The IWI: International Women's Initiative, "Street Harassment: The Inadequacy of European Laws", The IWI: International Women's Initiative, April 9, 2020, accessed from https://www.theiwi.org/gpr-reports/belgium-france-portugal-catcalling-law.

18 Putri Widi Saraswasti, "Catcalling: Pelecehan Terhadap Perempuan", Putri Widi Saraswati, November 29, 2015, accessed from https://putriwidisaraswati.wordpress.com/2015/11/29/catcallingpelecehan-terhadap-perempuan/.

${ }^{19}$ Mansour Fakih, Analisis Gender dan Transformasi Sosial, Pustaka Pelajar, Yogyakarta, 1996, p. 12 
or the perception of insignificance in a political decision; (3) Stereotyping or negative labeling; (4) more extended and more workload (multi-burden), (5) violence; and (6) socialization of gender role values ideology. All forms of gender injustice cannot be separated because they are related to one another and socialized, standardized through political, religious, social, economic systems, including Law. ${ }^{20}$

According to research conducted by YouGov in 2014, Jakarta was ranked 5 (five) as the city with the highest rate of verbal abuse against women. In 2021, a survey conducted by L'Oreal - IPSOS Indonesia in January found that 82 percent of Indonesian women interviewed admitted to having been harassed in public places. This figure is higher than the average of the other 8 countries surveyed and the most concerning, 91 percent of respondents said they did not know what to do to help victims. This shows that people's understanding of catcalling is still lacking. The government in this case also needs socialization to the public regarding sexual harassment and its forms, including catcalling.

Protection of victims and their human rights is important. As this is also guaranteed in the objectives of the Unitary State of the Republic of Indonesia which states that it protects the entire nation and spills Indonesian blood. In fact, this is also expressed in Article 28G paragraph (1) of the 1945 Constitution of the Republic of Indonesia which explains that every person has the right to protection for himself, family, honor, dignity and property under his control, as well as the right to a sense of security and protection from the threat of fear for do and not do something that is a human right. This is then confirmed in Article 29 paragraph (1) of the Human Rights Law which states that everyone has the right to a sense of security and security and protection against the threat of fear to do or not do something. Then Article 35 of the Human Rights Law also states that everyone has the right to live in a peaceful, safe, and serene society and state order, respects, protects and fully implements human rights and essential human obligations as regulated in this Law.

Moving on from the Human Rights Law, Lawrence Meir Friedman stated that every legal system consists of 3 (three) sub-systems, namely the

${ }^{20}$ Fakih, Ibid., p. 13-23. 
legal substance, legal structure, and legal culture. The legal form is related to law enforcement agencies or institutions. The essence of the Law is the whole legal principles, legal norms and legal rules, both written and unwritten. According to Friedman, legal culture is human attitudes towards Law and the legal system - beliefs, values, thoughts, and expectations. Referring to Friedman's theory, in regulating catcalling acts in Indonesia, the existing legal substance has not firmly held and ensnared the perpetrators. This is evidenced by the high number of sexual harassment in the street. In handling catcalling cases, law enforcement officers combine articles in the Criminal Code and Law Number 44 the Year 2008 concerning Pornography (Pornography Law). The articles in the Criminal Code that are used are Article 281 point (2), which regulates that if someone deliberately in front of another person against the will of that person, then commits an action or act that is contrary or violates morality, then he can be sentenced to prison or fine. Furthermore, Article 315 of the Criminal Code regulates that every insult committed by a person deliberately against another person before the public (public face) orally or in writing, or in front of the person himself orally or indeed, or through a letter sent and received by the person concerned is categorized as a criminal act in the form of imprisonment or a fine. Then the articles in the Pornography Law used are Article 34 jo. Article 8 and Article 35 in conjunction with Article 9 of the Pornography Law. The provisions in Article 34 jo. Article 8 of the Pornography Law outlines the imposition of imprisonment and/or fines for any person with an intentional element or with his consent becoming himself an object or public material containing pornographic content. Then in Article 35 jo. Article 9 of the Pornography Law regulates the granting of imprisonment and/or fines for damages to anyone who makes another person an object or public material containing pornographic content.

The provisions of the Criminal Code and the Pornography Law have not been able to resolve catcalling cases. The articles in the Criminal Code have not explained in detail what is meant by actions or actions that are contrary to or violate decency because the perspective of society regarding activities that are contrary or violate morality is different in each place. In addition, the act of catcalling is not an insult but a compliment that makes the victim feel insecure and threatened. Then, the provisions in the Pornography Law do not guarantee legal certainty due to the emphasis on the four articles on "it is prohibited to make oneself or others as objects or models that contain 
pornographic content and are contrary to decency." It is not explained by what kind of action. Therefore, it can be concluded that there is a legal vacuum in regulating catcalling acts in Indonesia. There are no clear and transparent laws and regulations regarding catcalling.

\begin{tabular}{|c|c|c|}
\hline & Indonesia & France \\
\hline 1. Regulations & $\begin{array}{l}\text { - Criminal } \\
\text { (KUHP). The articles } \\
\text { used in the Criminal } \\
\text { Code are Article } 281 \\
\text { point (2), Article } 315 \\
\text { - Law Number } 44 \text { of } \\
2008 \text { concerning } \\
\text { Pornography. The } \\
\text { article used in the } \\
\text { Pornography Law is } \\
\text { Article } 34 \text { jo. Article } 8 \text {, } \\
\text { Article } 35 \text { jo. Article } 9 .\end{array}$ & $\begin{array}{l}\text { Loi } n^{\circ} 2018-703 \text { du } 3 \text { août } \\
2018 \text { renforçant la lutte } \\
\text { contre les violences } \\
\text { sexuelles et sexistes (Loi } \\
\text { Schiappa). } \\
\text { [UU No. 2018 }-703 \\
\text { dated August } 32018 \\
\text { Strengthening the } \\
\text { Eradication of Sexual } \\
\text { and Gender-Based } \\
\text { Violence (UU Schiappa)]. }\end{array}$ \\
\hline $\begin{array}{l}\text { 2. Catcalling } \\
\text { Definition }\end{array}$ & $\begin{array}{l}\text { There is no definition of } \\
\text { catcalling in Indonesian } \\
\text { legislation, but law } \\
\text { enforcers often combine } \\
\text { articles in the Criminal } \\
\text { Code and the } \\
\text { Pornography Law. } \\
\text { Article } 281 \text { point (2) of } \\
\text { the Criminal Code } \\
\text { stipulates that if a person } \\
\text { deliberately acts in front } \\
\text { of another person against } \\
\text { the will of that person, } \\
\text { then commits an action or } \\
\text { act that is contrary to or } \\
\text { violates decency, he can } \\
\text { be sentenced to } \\
\text { imprisonment or a fine. }\end{array}$ & $\begin{array}{l}\text { Under Articles 222-33-2-2 } \\
\text { of the French Criminal } \\
\text { Code, sexual harassment } \\
\text { is defined as coercing } \\
\text { someone, repeatedly, } \\
\text { making comments or } \\
\text { behavior with sexual or } \\
\text { sexist connotations that } \\
\text { are degrading their } \\
\text { dignity on the grounds } \\
\text { of being degrading or } \\
\text { humiliating in nature or } \\
\text { creating resistance to } \\
\text { something intimidating, } \\
\text { a situation. hostile or } \\
\text { offensive. } \\
\text { Then after Loi Schiappa, } \\
\text { after this paragraph }\end{array}$ \\
\hline
\end{tabular}




\begin{tabular}{|c|c|c|}
\hline & $\begin{array}{l}\text { Furthermore, in the } \\
\text { elucidation of Article } 9 \text { of } \\
\text { the Pornography Law, it } \\
\text { is clear that every person } \\
\text { is prohibited from } \\
\text { making other people } \\
\text { objects or models that } \\
\text { contain pornographic } \\
\text { content. }\end{array}$ & $\begin{array}{l}\text { three paragraphs are } \\
\text { inserted as follows: } \\
\text { "The offense is also a : } \\
\text { a) When this comment or } \\
\text { behavior is imposed } \\
\text { on the same victim by } \\
\text { several people, } \\
\text { collectively or at the } \\
\text { instigation of one of } \\
\text { them, even though } \\
\text { each of these people } \\
\text { did not act repeatedly; } \\
\text { b) When these comments } \\
\text { or behaviors were } \\
\text { charged to the same } \\
\text { victim, successively, } \\
\text { by several people } \\
\text { who, even without } \\
\text { consultation, knew } \\
\text { that this comment or } \\
\text { behavior characterized } \\
\text { repetition. }\end{array}$ \\
\hline 3. Material Content & $\begin{array}{l}\text { Actions or acts of } \\
\text { violation of the norms of } \\
\text { decency in society. }\end{array}$ & $\begin{array}{l}\begin{array}{l}\text { Limitation of sexual } \\
\text { crimes }\end{array} \\
\text { against }\end{array}$ \\
\hline 4. Punishment & $\begin{array}{l}\text { Imprisonment and/or } \\
\text { compensation fines. } \\
\text { Based on Article } 35 \text { of the } \\
\text { Pornography Law, it is } \\
\text { explained that every }\end{array}$ & $\begin{array}{l}\text { Fines of up to } 700 \text { euros } \\
\text { or } 1,500 \text { euros if there are } \\
\text { aggravating } \\
\text { circumstances such as } \\
\text { victims under } 15 \text { years of }\end{array}$ \\
\hline
\end{tabular}




\begin{tabular}{|c|c|c|}
\hline & $\begin{array}{l}\text { person who makes other } \\
\text { people as objects or } \\
\text { models containing } \\
\text { pornographic content as } \\
\text { referred to in Article } 9 \\
\text { will be subject to } \\
\text { imprisonment for a } \\
\text { minimum of } 1 \text { year and a } \\
\text { maximum of } 12 \text { years and } \\
\text { / or a fine of at least IDR } \\
500,000,000.00 \quad \text { five } \\
\text { hundred million rupiah) } \\
\text { and a maximum of Rp. } \\
6,000,000,000.00 \\
\text { billion rupiah). }\end{array}$ & age. \\
\hline $\begin{array}{l}\text { 5. Procedures for } \\
\text { Handling/ } \\
\text { Enforcement }\end{array}$ & $\begin{array}{l}\text { - The catcalling victim } \\
\text { reports to the police. } \\
\text { The police will follow } \\
\text { up on the victim's } \\
\text { report. } \\
\text { - After being processed, } \\
\text { the police will arrest } \\
\text { the perpetrator who is } \\
\text { accompanied by } \\
\text { sufficient evidence. } \\
\text { Perpetrators will be } \\
\text { subject to } \\
\text { imprisonment or a } \\
\text { fine. }\end{array}$ & $\begin{array}{l}\text { - Catcalling victims can } \\
\text { immediately report to } \\
\text { the police on the street } \\
\text { or nearby places. } \\
\text { - Then, the police will } \\
\text { provide a fine on the } \\
\text { spot to the } \\
\text { perpetrator. }\end{array}$ \\
\hline
\end{tabular}

Table 1. Comparison of Catcalling Arrangements in Indonesia and France

Women must be protected from all threats and violence. In this connection, a law that regulates catcalling is needed. This catcalling arrangement can emulate the French model that ensnares catcallers with spot fines. This catcalling arrangement is necessary because one of the objectives of 
the Law is the achievement of public welfare, therefore actions that cause harm to society, including the victim, must be criminalized. This is of course also in line with the purpose of the punishment which can be outlined to improve the perpetrator's self, to make people deterred from committing crimes and to make certain criminals unable to commit other crimes, criminals who in other ways, are no longer able to commit crimes. Can be fixed again. ${ }^{21}$

Criminal punishment with a fine for catcalling was chosen because, as previously explained, the use of imprisonment tends to be less effective. Generally, catcalling victims do not report cases of sexual harassment to the police. In addition, the lack of evidence of sexual harassment experienced by victims makes victims less likely to say it and when reporting cases are not continued. Therefore, the French model can be tried in the criminalization of catcalling acts in Indonesia. Because in practice in France, there are already more than 700 people who are fined on the spot in a year. Apart from being fined, the catcalling actor will also be educated about catcalling and its effects. Giving fines to the perpetrators of catcalling also makes people understand what catcalling is so that it will be an advancement in gender equality between men and women.

Mochtar Kusumaatmadja once stated that law functions to change people's mindset or a means of community renewal. Furthermore, Friedman's theory states that the success or failure of law enforcement depends on the substance of the Law, the legal structure and legal culture. Legal culture is closely related to the legal awareness of society. The higher the legal awareness of the community will create a good legal culture and can change the community's mindset regarding the Law so far. In simple terms, the level of public compliance with the Law is one indicator of the functioning of the Law. From the explanation of Lawrence M. Friedman, legal culture is a vital thing in the legal system, namely a "demand", "request" or "need" that comes from society or users of legal services related to ideas, attitudes, beliefs, expectations. And opinions on the Law. Therefore, the legal culture of society can also be interpreted as the values and attitudes, and behavior of community members in community life. The legal culture of a society can also be given the same limitations as legal awareness. From the individual side, legal awareness is the awareness or values that exist in humans about existing laws or laws expected to live. In fact, what is emphasized is the values

${ }^{21}$ P.A.F. Lamintang, Hukum Penitensier indonesia, CV Armico, Bandung, 1989, p. 10-11. 
regarding the function of Law and not a legal assessment of concrete events in the society concerned. Public legal awareness is one of the factors for effective law enforcement, in addition to legal factors, law enforcement, supporting facilities, and legal culture. ${ }^{22}$

For Kant, humans are creatures of reason and free will. The state has to uphold the rights and freedoms of its citizens. The prosperity and happiness of the people are the state's goals and Law, therefore, these fundamental rights should not be obstructed by the state. The fundamental rights inherent in human beings are natural, universal, and eternal as a gift from God Almighty, including the right to life, the right to have a family, the right to self-development, the right to justice, the right to freedom, the right to communicate, the right to security, and the right to welfare, therefore, no one should ignore or take away. According to Fitzgerald, he explained Salmond's theory of legal protection that Law aims to integrate and coordinate various interests in society because, in traffic of interests, protection of certain interests can only be done by limiting various interests on the other side. The interest of Law is to take care of human rights and interests so that the Law has the highest authority to determine human interests that need to be regulated and protected. Legal protection must look at the stages, namely legal protection born from a lawful provision and all legal regulations provided by the community, which are a community agreement to regulate the behavioral relationships between community members and between individuals and the government which are considered to represent the interests of the community. ${ }^{23}$

However, the catcalling arrangement in Indonesia with the French model will require a lot of police. The police must be available in various places on the street and in public places to see and give fines on the spot to the catcallers. This of course becomes a new problem. Therefore, in this case the police can use CCTV recording devices that are placed in every street and public place. Then, the police can coordinate with the CCTV officers. That way, in every street and place, only one policeman is needed to take action and find the perpetrators of the catcalling on the spot.

\footnotetext{
22 Soerjono Soekanto, Faktor-Faktor Yang Mempengaruhi Penegakan Hukum, Cetakan Kelima, Raja Grafindo Persada, Jakarta, 2004, p. 42.

${ }^{23}$ Ateng Karsoma, Perlindungan Hukum Hak Paten Aphankam, PT Penerbit, Bandung, 2020, p. 36.
} 


\section{CONCLUSION}

From the above study, in general, it can be concluded that the regulation of catcalling acts in Indonesia is crucial because there are so many victims of catcalling that it tends to increase every year. The Indonesian constitution has regulated the right to security which is the right of every human being, including women. This has been confirmed in Article 30 of Law Number 39, Year 1999, concerning Human Rights. These human rights should not be ignored or even taken away by anyone. Law aims to integrate and coordinate various interests in society because in traffic of goods, protection of certain interests can only be done by limiting the multiple interests of other parties. In several countries, there have been regulations regarding catcalling, France is one of them. France imposes direct fines on the spot for catcallers. The selection of direct fines on the spot was chosen because prison terms for catcallers such as in Belgium are ineffective. Due to a lack of evidence. Fines carried out in France are proven to be effective because in a year, there have been more than 700 people who have been fined and the public has become educated with sexual harassment, including catcalling. There is no regulation regarding catcalling in Indonesia, so there is a legal vacuum. Indonesia can follow the model of the French catcalling arrangement, which uses direct fines on the spot. This punishment is in line with the purpose of the sentence: to improve the perpetrator's personal self, deter him from committing sexual harassment, and prevent the perpetrator from engaging in sexual harassment in any other way.

\section{DECLARATION OF CONFLICTING INTERESTS}

None

\section{FUNDING INFORMATION \\ None}

\section{ACKNOWLEDGEMENT}

I want to express my gratitude to my parents, siblings, and colleagues in the Battle of Speech Faculty of Law, Tarumanagara University, who supported me in completing this research article properly. 


\section{REFERENCES}

Batha, E. (August, 2019). "France Fines More Than 700 in First Year of 'Catcall' law", Reuters, August 6, 2019, accessed form https://www.google.com/amp/s/mobile.reuters.com/article/amp/idUSK CN1UW1NY.

Brox Sáenz de la Calzada, A. (2019). Acoso sexista callejero: Qué respuesta puede ofrecer el Derecho penal? (Sexist Street Harassment: What Kind of Answer Can the Penal Law Provide?), Oñati Socio-Legal Series (online), 9(6), 983-1000. https://doi.org/10.35295/osls.iisl/00000000-0000-1080.

Brundsdon, D. (2018). Legal Solutions to Street Sexual Harassment in the \#MeToo Era, Atlantis, 39(2), 40-56. https://doi.org/10.7202/1064071ar.

Chazawi, A. (2005). Tindak Pidana Mengenai Kesopanan. Jakarta: Rajagrafindo. Criminal Code.

Dewan Perwakilan Rakyat. (2017). Naskah Akademik Rancangan UndangUndang tentang Penghapusan Kekerasan Seksual, accessed from https://www.dpr.go.id/dokakd/dokumen/RJ1-20170307-0911055895.pdf.

Dewi, I. A. A. (2019). Catcalling: Candaan, Pujian atau Pelecehan Seksual, Acta Comitas Jurnal Hukum Kenotariatan, 4(2), 198-212. https://doi.org/10.24843/AC.2019.v04.i02.p04.

Efendi, J., Ibrahim, J. (2018). Metode Penelitian Hukum: Normatif dan Empiris. Depok: Prenadamedia Group.

Fakih. (1996). Analisis Gender dan Transformasi Sosial. Yogyakarta: Pustaka Belajar.

Fileborn, B. (2016). Justice 2.0: Street Harassment Victims' Use Of Social Media And Online Activism As Sites Of Informal Justice, British Journal Of Criminology, 57(6), 1482-1501. https://doi.org/10.1093/bjc/azw093.

Fileborn, B., Gray, F.V. (2017). I Want to be Able to Walk the Street Without Fear: Transforming Justice for Street Harassment, Feminist Legal Studies, 25(2), 203-227. https://doi.org/10.1007/S10691-017-93503-3.

Fillion, S. (Januarr, 2021). "2 Years Later, What We Can Learn From France's Anti-Catcalling Law", Forbes, January 26, 2021, accessed from https://www.forbes.com/sites/stephaniefillion/2021/01/26/2-years-laterwhat-we-can-learn-from-frances-anti-catcalling-law/?sh=208cdae375dc. 
Hébert, L. C. (2019). Dignity and Discrimination in Sexual Harassment Law: A French Case Study, Washington and Lee Journal of Civil Rights and Social Justice ,25(1), 1-38.

Karsoma, A. (2020). Perlindungan Hukum Hak Paten Aphankam. Bandung: PT Penerbit.

Kartika, Y., Najemi, A. (2020). Kebijakan Hukum Perbuatan Pelecehan Seksual (Catcalling) dalam Perspektif Hukum Pidana, Pampas: Journal of Criminal, 1(2). https://doi.org/10.2139/ssrn.3239557.

Lamintang, P. A. F. (1989). Hukum Penitensier indonesia. Bandung: CV Armico.

O' Leary, C. (2016). Catcalling As a "Double Edged Sword": Midwestern Women, Their Experiences, and The Implications of Men's Catcalling Behaviors, Theses and dissertation, Illinois State University. https://ir.library.illinoisstate.edu/cgi/viewcontent.cgi?article=1534\&cont ext=etd.

Putri, L. J., Suardita, I. K. (2019). Tinjauan Yuridis Terhadap Perbuatan Catcalling (Pelecehan Verbal) Di Indonesia. Kertha Wicara, 8(2), 1-15. https://ojs.unud.ac.id/index.php/kerthawicara/article/view/47598.

Republic of Indonesia. (2002). 1945 Constitution of Republic of Indonesia.

Republic of Indonesia. (2008). Law Number 44 of 2008 concerning Pornography. State Gazette Number 181 of 2008, Supplement to the State Gazette Number 4928. Available online on https://www.hukumonline.com/pusatdata/detail/28607/undangundangnomor-44-tahun-2008\#.

Rizky, P. A. (March, 2018). “Catcalling dan Mimpi Buruk Perempuan di Jalan", alinea.id, March 18, 2018, accessed from https://www.alinea.id/gaya-hidup/catcalling-dan-mimpi-burukperempuan-di-jalan-b1UvT9I8.

Saraswasti, P. W. (November, 2015). "Catcalling: Pelecehan Terhadap Perempuan", Putri Widi Saraswati, November 29, 2015, accessed from https://putriwidisaraswati.wordpress.com/2015/11/29/catcallingpelecehan-terhadap-perempuan/.

Simbolon, D. F. (2018). Minimnya Pendidikan Reproduksi Dini Menjadi Faktor Penyebab Terjadinya Pelecehan Seksual Antar Anak, Soumatera Law Review, $1(1)$, 43-46. https://media.neliti.com/media/publications/284753-kurangnyapendidikan-reproduksi-dini-men-37b7f836.pdf. 
Soekanto, S. (2004). Faktor-Faktor Yang Mempengaruhi Penegakan Hukum, Cetakan Kelima. Jakarta: Raja Grafindo Persada.

Tauratiya. (2020). Perbuatan Catcalling dalam Perspektif Hukum Positif. Ekspose: Jurnal Penelitian Hukum dan Pendidikan ,19(1), 1019-1025. https://doi.org/10.30863/ekspose.v1i1.690.

The IWI: International Women's Initiative. (April, 2020). "Street Harassment: The Inadequacy of European Laws", The IWI: International Women's Iniative, April 9, 2020, accessed from https://www.theiwi.org/gprreports/belgium-france-portugal-catcalling-law.

Tschapka, L. (2018). A Threat to Free Speech? Overcoming the Dilemma. UBT International Conference, $385 . \quad$ https://knowledgecenter.ubtuni.net/cgi/viewcontent.cgi? article=2007\&context=conference.

Wilkes, E. (February, 2021). "The Dangerous Impact of Catcalling on Women", The boar, February 11, 2021, accessed from https://theboar.org/2021/02/catcalling-experiences/. 


\section{ABOUT AUTHOR(S)}

Evelyne Julian Halim, a woman born in Jakarta, July 5, 2000, is a student at the Faculty of Law, Tarumanagara University. Active on campus by joining the student activity unit, namely the Battle of Speech, Faculty of Law, Tarumanagara University. Also active in committees held on campus internally such as the 2019 Tarumanagara Internal Law Competition and the 2020 Tarumanagara Internal Law Competition, Faculty of Law, Tarumanagara University. In the organizational structure of the student activity unit, Battle of Speech serves as the head of the Writing Division. Some of the competitions he has participated in include, Padjajaran Law Fair XI Constitutional Drafting Competition, 2019 People's Consultative Assembly Constitutional Drafting Competition, 2020 Legislative Drafting Sciencesational Competition, Faculty of Law, University of Indonesia, Mining Law Essay Competition - Center for Energy and Mining Law Studies 2020, Scientific Writing Competition Semarang State University Law Festival 2020 and many more. One of the achievements that have been achieved is being included in the list of outstanding students of the Faculty of Law UNTAR 2021. 